\title{
The Effect of Understanding and Application of Accounting Information System on SMEs Culinary Performance in Manado City
}

\author{
Victorina Z. Tirajoh*, Yunita Mandagie, Meily Y. B. Kalalo \\ Faculty of Economy and Business \\ Universitas Sam Ratulangi \\ Manado, Indonesia \\ *vtirayoh@unsrat.ac.id
}

\begin{abstract}
The purpose of this study is to determine the understanding application of accounting information systems that influences the performance of culinary SMEs in the city of Manado. There are several research questions which are: does the application of accounting information systems affect the performance of culinary SMEs in the city of Manado? Does the understanding and application of accounting information systems affect the performance of culinary SMEs in the city of Manado? The research method used is multiple regression analysis with the help of the SPSS program. The results of the study found that there are influences of variables studied with the performance of SMEs. Study of factors affecting domestic tourism purchase in SME food and beverage based in Manado City.
\end{abstract}

Keywords: understanding, application, accounting information systems, SMEs, performance

\section{INTRODUCTION}

Micro, Small and Medium Enterprises are often abbreviated MSMEs today as an effective way to reduce poverty. From the statistics and research carried out, MSMEs represent the largest number of business groups. MSMEs have been legally regulated through Law Number 20 of 2008 concerning Micro, Small and Medium Enterprises [1].

MSMEs are the largest economic group in the Indonesian economy and are proven to be the safety valve of the national economy in times of crisis, as well as a dynamic economic growth after the economic crisis. In addition to being the business sector with the largest contribution to national development, MSMEs also create sizable employment opportunities for domestic workers, thus greatly helping efforts to reduce unemployment.

The central government in this regard is very concerned about the development and survival of MSMEs through various programs that are rolled out to help and pay attention to the existence of MSMEs. With the current development and progress, of course, indirectly creates intense competition faced by every business, so MSMEs must, of course, continue to try to maintain and even improve their competitiveness so that they can exist in the market. MSMEs are demanded to continue to innovate along with the changing times, and this is a concern because MSMEs depart from the home industry or family.

Manado City, the capital of North Sulawesi Province, is a city that is a tourist destination for both domestic and foreign tourists. The real evidence of 2017 according to data from the Central Statistics Agency (BPS) shows that the number of foreign tourists coming to North Sulawesi via Sam Ratulangi Airport reached 23,832 in January-April 2017 [2]. The number grew by $388 \%$ compared to the same period last year. The number of foreign tourists visiting North Sulawesi in the January-April 2017 period was also equivalent to 58\% of the total foreign tourist visits throughout 2016. Head of BPS of North Sulawesi said that until now tourists from China still dominate foreign tourist visits to North Sulawesi [3]. As of April 2017, mainland China tourists has indeed become a major market share. Cumulatively in the four months of 2017 , the number of travelers from the mainland China reached 19,289 or $81 \%$ of the total foreign tourists visiting North Sulawesi. To note, tourists from China increased rapidly since direct charter flights from eight cities in China opened in June 2016. This situation triggered the emergence of new MSMEs engaged in the food and beverage sector or the culinary sector.

As the economic principle of increased demand will certainly encourage the creation of supply. The entry of new competitors will certainly make the existing competition even tighter so that inevitably the existing MSMEs must improve their performance so as not to lose in the existing competition. Because the role of MSME is also very large in the Indonesian economy, efforts to improve the performance of MSME itself are absolutely necessary so that economic stability can be maintained, one of which is through understanding and applying Accounting Information Systems.

The purpose of this study was to analyze the influence of understanding and application of accounting information systems on the performance of culinary MSMEs in the city of Manado. 


\section{THEORETICAL FRAMEWORK}

\section{A. Small and Medium Enterprises (SMEs)}

Micro, Small and Medium Enterprises (MSMEs) have different definitions in each literature according to several institutions or even laws. In accordance with Law number 20 of 2008 concerning Micro, Small and Medium Enterprises, MSMEs are defined as follows [1]:

(1) Micro businesses are productive businesses owned by individuals and/or individual business entities that meet the criteria for Micro Business as regulating in this Act. (2) Small Business is a productive economic business that stands alone, which is carried out by individuals or business entities that are not subsidiaries or branch companies that are owned, controlled, or become a part either directly or indirectly of Medium Enterprises or Large Enterprises that fulfill Small Business criteria as referred to in this Act. (3) Medium Business is a productive economic business that stands alone, which is carried out by an individual or business entity that is not a subsidiary or branch of a company that is owned, controlled, or becomes a part either directly or indirectly with a Small Business or Large Business with the amount of wealth net or annual sales results as provided for in this Law.

Based on wealth and sales results, according to Law Number 20 of 2008 article 6, the criteria for micro-businesses are [1]: (1) Having a net asset of no more than Rp $50,000,000.00$ (fifty million rupiahs) excluding land and buildings where the business is located; or (2) Having annual sales results of at most Rp. 300,000,000.00 (three hundred million rupiahs).

The criteria for small businesses are as follows [1]: (1) Having a net asset of more than Rp 50,000,000.00 (fifty million rupiahs) up to a maximum of $\mathrm{Rp} 500,000,000.00$ (five hundred million rupiahs) excluding land and buildings where the business is located; or (2) Having annual sales results of more than Rp. 300,000,000.00 (three hundred million rupiahs) up to a maximum of $\operatorname{Rp} 2,500,000,000.00$ (two billion five hundred million rupiahs).

The criteria for medium-sized businesses are as follows [1]: (1) Having a net asset of more than $\mathrm{Rp} 500,000,000.00$ (five hundred million rupiahs) up to a maximum of $\mathrm{Rp}$ $10,000,000,000.00$ (ten billion rupiahs) excluding land and buildings where the business is located; or (2) Having annual sales results of more than $\mathrm{Rp} 2,500,000,000.00$ (two billion five hundred million rupiah) up to a maximum of $\mathrm{Rp}$ $50,000,000,000.00$ (fifty billion rupiahs)

\section{B. Accounting Information System}

Information systems are needed by companies to process data into information so that various parties making decisions can use the information to make good decisions. Understanding accounting information systems according to Mulyadi [4] states that: The accounting system is an organization of forms, records, and reports that are coordinated in such a way as to provide the financial information needed by management to facilitate the management of the company. Accounting Information System is an organizational component that collects, classifies, processes, analyzing and communicating financial information and relevant decision making to external and internal parties. AIS is defined which is: a set of HR and capital in an organization, whose job is to prepare financial information and also information obtained from transaction data collection and processing activities [5]. AIS has defined: a collection of human resources (human and equipment) that are organized to process data into information [6].

Another definition of an Accounting Information System is a component in a company that collects, classifies, processes, analyzes and communicates financial information and makes a decision that is relevant to external parties and internal companies. Accounting information systems are a unified structure within an entity, which uses physical resources and other components, to convert financial/accounting transaction data into accounting information with the aim of meeting the information needs of users or users [7]. Accounting information systems as subsystems of management information systems that provide accounting and financial information, such as information generated from routine accounting transaction processes [8]. It was concluded that the accounting information system is a combination of various resources that are designed to process existing accounting and financial data and convert it into information needed by the company for decision making.

The main functions of accounting information systems [4]

- Collecting and storing data about the organization's business activities efficiently and effectively: a) Capture transaction data on source documents. b) Record transaction data in journals, where the record is made chronologically from what has happened. c) Posting data from journals to the general ledger, which abbreviates data by account type.

- It provides information that is useful for management decisions. In a manual system, this information is provided in the form of reports into two main categories: a) Financial statements. b) Managerial Report

- Provide adequate internal control (sufficient). Ensuring that information produced by the system is reliable and can be trusted: a) Ensuring that business activities are carried out efficiently and in accordance with management objectives. b) Secure (protect) the wealth of the organization/company, including data.

The objectives of establishing an accounting information system are [9]:

- To support the management stewardship function. Management refers to the responsibility of management to properly manage company resources. Information systems provide information about the use of resources to external users through traditional financial reports and other requested reports. Internally, management receives management information from various accountability reports

- To support management decision making. Information systems provide managers with the information they 


\section{RESULTS AND DISCUSSION}

support the company's day-to-day operations. The information system provides information for operating personnel to help them carry out their daily tasks efficiently and effectively. is to support the company's operations in increasing the efficiency and effectiveness of the company's operational activities, especially in the process of accounting information flow.

\section{SME Performance}

For each organization, an assessment of performance is very important because the assessment can be used as a measure of the success of an organization in a certain period of time. The assessment can be used as input for improving or improving the performance of the organization concerned. One that can be used to assess the performance of a company is financial statements. Where financial statements are one source of information that is needed by users of financial statements both internal and external parties in making decisions in accordance with the needs of each user. An important part that becomes a measurement tool and is often used to assess the performance of a company is the level of profitability. The level of profit or loss of a company can be seen in the income statement issued by the company. The rate of profit cannot be ascertained or decreased.

Not all performance measurements at large companies can be applied to MSMEs due to the simplicity of the existing statements in MSMEs. Not all MSMEs publish financial reports, most MSMEs only record the gross circulation. In this study, business performance measures are assessed through Return on Assets (ROA) [10].

\section{METHOD}

\section{A. Sample and Procedure}

For the purposes of the survey, locations taken were around the food and beverage-based MSMEs in Manado City. Sampling is by sampling convenience or samples based on convenience, as well as purposive sampling or samples based on certain criteria. The Research respondents were 110 respondents.

Data analysis in this study using SPSS computer program. Research variables consist of dependent variable and independent variable. The dependent variable is SME performance, while the independent variables are understanding of accounting information systems, and application of accounting information systems.

\section{B. Measurement Procedures}

The study was conducted by surveying 110 respondents in 11 districts located in the city of Manado. Respondents are small businesses engaged in food and beverage based industries. The survey was conducted in mid-2019. The survey was conducted for two months and the response rate for filling out the questionnaire was 100 percent. Furthermore, the data taken entirely can be used for further data analysis.
TABLE I. SUMMARY OF RESEARCH RESPONDENTS DESCRIPTION

\begin{tabular}{|l|l|c|c|}
\hline \multicolumn{1}{|c|}{ Description } & \multicolumn{1}{|c|}{ Info } & Total & Per cent (\%) \\
\hline Gender & Men & 46 & 41.8 \\
& Woman & 64 & 58.2 \\
\hline Age (years old) & $21-30$ & 12 & 10.9 \\
& $31-40$ & 14 & 12.7 \\
& $41-50$ & 65 & 59.1 \\
& $>50$ & 19 & 17.3 \\
\hline Monthly Turn & $<10$ millions & 14 & 12.7 \\
Over (IDR) & 10 millions -50 millions & 69 & 62.7 \\
& $>50$ millions & 27 & 20 \\
\hline TOTAL & & 110 & 100 \\
\hline
\end{tabular}

Based on Table 1, respondents are 64 women, 65 respondents are aged between 41-50 years old and, have a turnover of between IDR 10 millions to IDR. 50 million per month about 69 respondents.

Instrumental test using validty and reliability test. This test using IBM SPSS programe ver 22. Results of validity and reliability show in tables below.

TABLE II. VALIDITY TEST

\begin{tabular}{|l|c|c|c|c|}
\hline \multirow{2}{*}{ Variables } & \multirow{2}{*}{ Indicators } & \multicolumn{3}{|c|}{ Correlation (r) } \\
\cline { 2 - 5 } & & $\mathbf{R}$ & Sig & Explanation \\
\hline \multirow{3}{*}{$\begin{array}{l}\text { AIS } \\
\text { Understanding } \\
\left(\mathrm{X}_{1}\right)\end{array}$} & $\mathrm{X} 1.1$ & 0.611 & 0.000 & Valid \\
\cline { 2 - 5 } & $\mathrm{X} 1.2$ & 0.942 & 0.000 & Valid \\
\cline { 2 - 5 } & $\mathrm{X} 1.3$ & 0.883 & 0.000 & Valid \\
\cline { 2 - 5 } & $\mathrm{X} 1.4$ & 0.779 & 0.000 & Valid \\
\hline \multirow{3}{*}{$\begin{array}{l}\text { AIS } \\
\text { Implementation }\end{array}$} & $\mathrm{X} 2.1$ & 0.899 & 0.000 & Valid \\
\cline { 2 - 5 } & $\mathrm{X} 2.2$ & 0.945 & 0.000 & Valid \\
\cline { 2 - 5 } & $\mathrm{X} 2.3$ & 0.962 & 0.000 & Valid \\
\cline { 2 - 5 } & $\mathrm{X} 2.4$ & 0.840 & 0.000 & Valid \\
\cline { 2 - 5 } $\begin{array}{l}\text { SMEs } \\
\text { Implementation } \\
(Y)\end{array}$ & $\mathrm{X} 2.5$ & 0.924 & 0.000 & Valid \\
\cline { 2 - 5 } & $\mathrm{Y} 1.1$ & 0.978 & 0.000 & Valid \\
\hline \multirow{2}{*}{} & $\mathrm{Y} 1.2$ & 0.977 & 0.000 & Valid \\
\hline
\end{tabular}

Based on test shown that all of the variables are valid with a high significant level (at the 0.01 level). It is valid with correlation coefficient more than 0.30 . So, after using validity test, we conclude that all of variables are valid. Reliability test has shown in the Table 2 below:

TABLE III. RELIABILITY TEST

\begin{tabular}{|l|c|c|}
\hline \multirow{2}{*}{ Variables } & \multicolumn{2}{c|}{ Coeficient } \\
\cline { 2 - 3 } & Alpha Cronbach & Explanation \\
\hline AIS Understanding $\left(\mathrm{X}_{1}\right)$ & 0.942 & Reliable \\
\hline AIS Implementation $\left(\mathrm{X}_{2}\right)$ & 0.811 & Reliable \\
\hline SMEs Implementation $(\mathrm{Y})$ & 0.952 & Reliable \\
\hline
\end{tabular}

Based reliability test, all variables in this study measure a reliable value. This is in shown in Cronbach Alpha value is generated each variable is above the critical value. The value must above 0.60 that indicates reliable test for research instrument. 
Linear regression is a test to see how the independent variables influence the dependent variable [11]. In this paper, we use multiple linear regression because we have some independent variables which we want to know the relation to the dependent variable. We have intention starting a formal business as the dependent variable. Independent variables consist of personal attitude, perceived social norms, and perceived behavioral control. Author also used SPSS software programme to analyze it and below is the result.

TABLE IV. MULTIPLE LINEAR REGRESSION ANALYSIS

\begin{tabular}{|l|c|c|c|c|l|}
\hline & $\begin{array}{c}\text { Regression } \\
\text { Coeef. (b) }\end{array}$ & $\begin{array}{c}\text { Std } \\
\text { Er }\end{array}$ & $\begin{array}{c}\text { t } \\
\text { (count) }\end{array}$ & Sig. & Desc \\
\hline Constanta & 3.728 & 1.093 & 3.410 & 0.001 & \\
\hline $\begin{array}{l}\text { AIS Understanding } \\
\text { X1) }\end{array}$ & 0.186 & 0.057 & 3.283 & 0.001 & Sig \\
\hline $\begin{array}{l}\text { AIS Implementation } \\
(\mathrm{X} 2)\end{array}$ & 0.094 & 0.043 & 2.190 & 0.031 & Sig \\
\hline \multicolumn{5}{|l|}{$\mathrm{Y}=3,728+0,186 \mathrm{X} 1+0,094 \mathrm{X} 2+\mathrm{e}$} \\
\hline $\mathrm{R}$ & $=$ & 0.419 \\
\hline $\mathrm{R}$ Square & $=$ & 0.176 \\
\hline $\mathrm{F}$ count & $=$ & 11,414 \\
\hline $\mathrm{t}$ table & $=$ & 2,008 \\
\hline Sig. F & $=$ & 0.000 & \\
\hline $\mathrm{n}$ & $=$ & 110 & \\
\hline$\alpha$ & $=$ & $0.05(5 \%)$ \\
\hline
\end{tabular}

The formulation of the hypotheses tested was stated previously with the significance level used in this study of 5\% or $\alpha=0.05$, the results of testing the hypothesis are as follows:

\section{A. Hypothesis 1}

Using the help of the SPSS program, the FCount results can be seen in Table 4. The FCount results $=11,414$ and F-table $=$ 2,400 . So it was found that F-count> F-table with a significance level sig $\mathrm{F}=0,000<0.05$, this shows that $\mathrm{H} 0 \neg$ was rejected and Ha was accepted. Thus the results of the F test stated that H0 was rejected and Ha was accepted, meaning AIS Understanding (X1), AIS implementation (X2), simultaneously had a significant effect on MSME Performance.

\section{B. Hypothesis 2}

From the T-test results in table 4 it can be seen that the AIS Understanding $(\mathrm{X} 1)$ variable $\mathrm{t}=3.283>\mathrm{T}$ table $=2.008$ and $\mathrm{a}$ significant level of $0.001<0.05$, it can be concluded that $\mathrm{Ha}$ is accepted and $\mathrm{H} 0$ is rejected or AIS Understanding (X1) has a significant effect on MSME performance.

\section{Hypothesis 3}

From the results of the T-test in table 4 it can be seen that the variable of AIS (X1) t-count $=3.190>t$-table $=2.008$ and $\mathrm{a}$ significant level of $0.031<0.05$, it can be concluded that $\mathrm{Ha}$ is accepted and $\mathrm{H} 0$ is rejected or AIS Implementation (X2) has a significant effect on MSME performance.

\section{Correlation Coefficient and Determination Coefficient}

Based on the results of calculations using the help of the SPSS program as shown in Table 4 , it can be seen that the value $(\mathrm{R})$ produced is 0.419 , which means it has a strong relationship. The value of $\mathrm{R}$ square is 0.176 or $17.6 \%$. It means that the influence of all independent variables, namely: AIS Understanding (X1), AIS Implementation (X2), to the independent variable MSME Performance is $17.6 \%$ and the remaining 0.824 or $82.4 \%$ is influenced other variables outside this study.

\section{CONCLUSION}

The results of research and discussion show that: (1) There is an influence of understanding accounting information systems and the implementation of accounting information systems to the performance of culinary MSMEs in the city of Manado. (2) There is an influence of understanding of accounting information systems on the performance of culinary MSMEs in the city of Manado. (3) There is an effect of the application of accounting information systems on the performance of culinary MSMEs in the city of Manado.

Suggestions from this study are as follows: (1) For further researchers it is recommended to use a larger sample so that the results further strengthen the findings of this study. (2) For further researchers, it is recommended to conduct MSMEs performance research in locations and other objects at other MSMEs both in the same field and in different industries, especially in the City of Manado and its surroundings.

\section{ACKNOWLEDGMENT}

This research was financially supported by the author and the Faculty of Economics and Business, Sam Ratulangi University (UNSRAT) Manado, Indonesia.

\section{REFERENCES}

[1] Goverment of Indonesian. Indonesian Law No. 20 of 2008 on Micro, Small, and Medium Enterprises. Jakarta; 2008.

[2] BPS. North Sulawesi in Number 2018, Manado: Biro Pusat Statistik, 2018.

[3] R. Maulana, Foreign Tourists Visit to North Sulawesi Increases 388\% [Internet]. Bisnis.com. 2017 [28 November 2019]. Retrieved from: https://traveling.bisnis.com/read/20170602/224/658714/javascript

[4] Mulyadi, Accounting System. Sistem Akuntansi, Jakarta: Salemba Empat, 2017.

[5] B. E. Cushing, Accounting Information System Manual Approach. Sistem Informasi Akuntansi Pendekatan Manual Praktika Penyusunan Metode, Yogyakarta: BPFE, 2013.

[6] G. H. Bodnar, and W. S. Hopwood, Accounting Information System, New Jersey: Prentice Hall, 2013.

[7] J. W. Wilkinson, and M. J. Cerullo, Accounting Information System Essentials, New York: John Wiley \& Sons, 2015.

[8] R.V. Dasaratha, and F.L. Jones, Accounting Information System. Sistem Informasi Akuntansi, Jakarta: Salemba Empat, 2009.

[9] J.A. Hall, Accounting Information System. Sistem Informasi Akuntansi, Jakarta: Salemba Empat, 2012.

[10] I. G. A. Imbayani, and I. D. M. Endiana, "Pengaruh Pemahaman dan Penerapan Sistem Informasi Terhadap Kinerja UMKM Pengrajin Genteng di Kabupaten Tabanan," Jurnal Ilmu Manajemen Mahasaraswati, vol. 6, no. (1), pp. 1-14, 2016.

[11] U. Sekaran, and R. Bougie, Research Methods. For Business: A Skill Building Approach, 5th ed. West Sussex UK: John Wiley \& Sons, 2010. 